\title{
ANALISIS STRUCTURAL EQUATION MODEL DENGAN PENDEKATAN BAYESIAN
}

\author{
H. Sain ${ }^{1}$ \\ Program Studi Statistik Jurusan Matematika FMIPA Universitas Tadulako \\ Jalan Soekarno-Hatta Km. 09 Tondo, Palu 94118, Indonesia. \\ 1hartayunisain@yahoo.com
}

\begin{abstract}
Abstrak
Dalam tulisan ini akan dibahas suatu pendekatan alternatif dalam structural equation model (SEM) yaitu menggunakan pendekatan Bayesian. Asumsi-asumsi yang dibutuhkan SEM tidak selalu dapat terpenuhi, khususnya pada kasus-kasus tertentu, misalnya ketika jumlah sampel kecil. Beberapa kelebihan SEM dengan pendekatan Bayesian antara lain adalah (1) metode Bayesian lebih menekankan pada penggunaan raw data individu daripada sampel matrik kovarian, (2) variabel laten dapat diestimasi secara langsung (3) pendekatan Bayesian menggunakan informasi prior. Dua model structural dicobakan untuk mengetahui hubungan yang berbeda antara keempat variabel laten: komitmen professional (KP), komitmen organisasional (KO), perilaku kinerja (PK), dan kinerja kerja (KK).
\end{abstract}

Kata Kunci $\quad$ : Bayesian, MCMC, Structural Equation Model, WinBUGS 14

\section{PENDAHULUAN}

SEM merupakan metode gabungan dari analisis regresi, analisis jalur, dan analisis faktor yang seringkali digunakan dalam penelitian di bidang ilmu sosial. Dalam tulisan ini akan dibahas suatu pendekatan alternatif dalam SEM yaitu menggunakan pendekatan Bayesian. Menurut Lee (2007), pemodelan dalam SEM melibatkan variabel laten yang mempunyai hubungan linier dan semua nilai observasinya berdistribusi multivariat normal. SEM akan menghasilkan persamaan yang valid apabila terpenuhi asumsi-asumsi yang dibutuhkan yaitu normal multivariat dan linieritas.

Asumsi-asumsi yang dibutuhkan SEM tidak selalu dapat terpenuhi, khususnya pada kasuskasus tertentu, misalnya ketika jumlah sampel kecil. Lee (2007) mengembangkan metode SEM dengan pendekatan Bayesian. Beberapa kelebihan SEM dengan pendekatan Bayesian antara lain adalah (1) metode Bayesian lebih menekankan pada penggunaan raw data individu daripada sampel matrik kovarian, (2) variabel laten dapat diestimasi secara langsung (3) pendekatan Bayesian menggunakan informasi prior. Penggunaan informasi prior sebagai informasi awal nilai parameter 
dalam model akan memberikan hasil yang lebih baik dalam menghasilkan statistik dari distribusi posterior. Di samping itu pendekatan Bayesian yang dipadukan dengan MCMC tetap reliabel untuk sampel yang kecil. Berdasarkan pada kelebihan-kelebihan SEM dengan pendekatan Bayesian di atas maka pada tulisan ini digunakan metode SEM dengan pendekatan Bayesian.

Dalam tulisan ini, digunakan suatu contoh dataset yang terdiri dari empat variabel tidak terukur dengan 21 variabel indikator dan 26 objek pengamatan. Keempat variabel tersebut adalah komitmen profesional (KP), komitmen organisasional (KO), perilaku kerja (PK) dan kinerja kerja (KK). Dalam tulisan ini digunakan dua model struktural yang berbeda dengan tujuan untuk melihat pola hubungan yang berbeda antar keempat variabel. Untuk mendukung analisis ini, digunakan suatu software statistika yaitu WinBUGS 14.

\section{METODE PENELITIAN}

\subsection{Structural Equation Modeling (SEM)}

Structural equation modelling (SEM) merupakan salah satu analisis multivariat. SEM merupakan alat analisis statistik yang menggabungkan analisis faktor dengan analisis regresi. SEM biasanya digunakan untuk membangun dan menguji model statistik dalam bentuk model sebab akibat. Permodelan persamaan struktural (SEM) adalah metodologi untuk mempresentasikan, mengestimasi, dan pengujian jaringan hubungan antara variabel yaitu variabel terukur dan variabel laten. Salah satu alasan maraknya penggunaan SEM dalam berbagai cabang ilmu adalah kenyataan bahwa SEM menyediakan metode-metode yang komprehensif untuk proses kualifikasi dan pengujian teori-teori yang bersifat substansif. Karakteristik utama lainnya dari SEM adalah bahwa SEM secara eksplisit mempertimbangkan kesalahan-kesalahan pengukuran yang banyak terjadi dalam berbagai disiplin ilmu.

Dengan SEM dapat dilakukan tiga kegiatan secara serempak, yaitu pemeriksaan validitas dan reliabilitas instrumen (setara dengan faktor analisis konfirmatori), pengujian model hubungan antar variabel laten (setara dengan Analisis Path) dan mendapatkan model yang bermanfaat untuk prakiraan atau peramalan (setara dengan dengan Model Struktural atau Analisis Regresi). Untuk lebih jelasnya dapat divisualisasikan seperti pada Gambar 1, yang terlihat jelas bahwa SEM merupakan pendekatan terintegrasi antara Measurement Model, Structural Mode/ dan Path Analysis. 


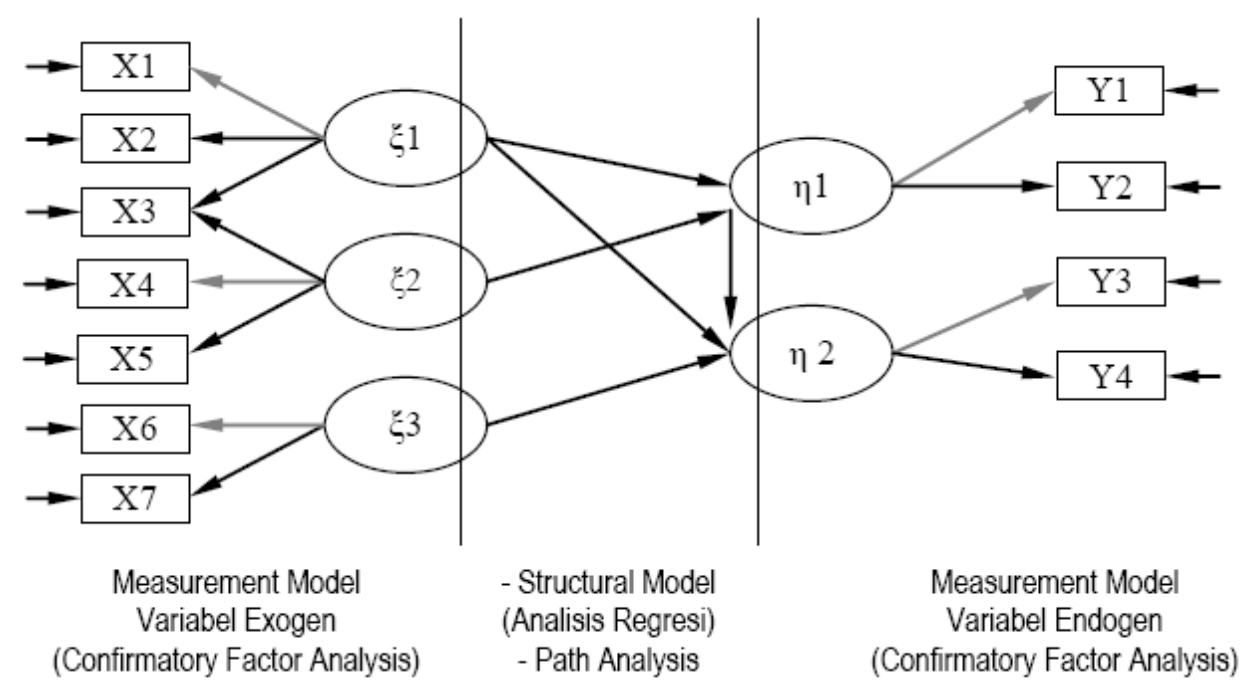

Gambar 1 : Structural Equation Modeling (SEM) (Solimun, 2002)

\subsection{Variabel-variabel dalam SEM}

Metode SEM melibatkan dua variabel yaitu variabel laten dan variabel teramati. Variabel laten merupakan konsep abstrak yang hanya dapat diamati secara tidak langsung dan tidak sempurna melalui efeknya pada variabel teramati. SEM mempunyai dua jenis variabel laten yaitu eksogen dan endogen. Variabel eksogen adalah variabel bebas pada semua persamaan yang ada dalam model. Sedangkan variabel endogen merupakan variabel terikat pada paling sedikit satu persamaan model. Notasi matematik dari variabel laten eksogen adalah $\xi(\mathbf{x i})$ dan variabel laten endogen ditandai dengan $\boldsymbol{\eta}$ (eta). Variabel teramati atau variabel terukur adalah variabel yang dapat diamati atau dapat diukur secara empiris dan sering disebut sebagai indikator. Variabel teramati merupakan efek atau ukuran dari variabel laten.

\subsection{Model-model dalam SEM}

a. Model Struktural

Model struktural menggambarkan hubungan-hubungan yang ada di antara variabel-variabel laten. Hubungan ini umumnya linier, meskipun perluasan SEM memungkinkan untuk mengikutsertakan hubungan non-linier. Parameter yang menunjukkan regresi variabel laten endogen pada variabel laten eksogen diberi notasi Y (gamma), sedangkan untuk regresi variabel laten endogen pada variabel laten endogen yang lain diberi notasi $\beta$ (beta). Dalam SEM matrik varian kovarian diberi notasi $\Phi$ (phi). Menurut Bollen (1989) model struktural untuk SEM dinyatakan dalam persamaan sebagai berikut: 


$$
\boldsymbol{\eta}=\boldsymbol{\beta} \boldsymbol{\eta}+\boldsymbol{\Gamma} \xi+\zeta
$$

dimana adalah $\boldsymbol{\xi}_{(p \times 1)}$ vektor random dari variabel laten eksogen dan $\boldsymbol{\eta}_{(q \times 1)}$ adalah vektor random dari variabel endogen. $\boldsymbol{\Gamma}_{(p \times p)}, \mathbf{B}_{(q \times q)}$ dan $\xi_{(q \times 1)}$ dengan asumsi $E(\eta)=0, E(\xi)=0, E(\zeta)=0$, tidak ada korelasi antara $\zeta$ dan $\xi$.

b. Model Pengukuran

Dalam SEM, setiap variabel laten mempunyai beberapa ukuran atau variabel teramati atau indikator. Dalam model ini, setiap variabel laten dimodelkan sebagai sebuah faktor yang mendasari variabel-variabel teramati yang terkait. Nilai loading factor yang menghubungkan variabel-variabel laten dengan variabel-variabel teramati diberi notasi $\lambda$ (lambda). Menurut Bollen (1989) model pengukuran dalam SEM dinyatakan dalam persamaan sebagai berikut:

$$
\begin{aligned}
& \mathbf{x}=\Lambda_{\mathrm{x}} \xi+\delta \\
& \mathbf{y}=\Lambda_{\mathrm{y}} \boldsymbol{\eta}+\boldsymbol{\varepsilon}
\end{aligned}
$$

dimana $\mathbf{x}_{(s \times 1)}$ dan $\mathbf{y}_{(t \times 1)}$ merupakan vektor random variabel pengamatan yang merupakan indicator untuk $\xi$ dan $\eta$, kemudian $s$ dan $t$ adalah baris matriks yang menunjukkan banyaknya variabel indicator. Sedangkan $\boldsymbol{\Lambda}_{x(s \times q 1)}, \boldsymbol{\Lambda}_{x(t \times q 2)}$ adalah matriks loading factor, kemudian $\boldsymbol{\delta}_{(s \times 1)}, \boldsymbol{\varepsilon}_{(t \times 1)}$ adalah vektor random dari kesalahan pengukuran. Diasumsikan $E(\eta)=0, E(\xi)=0, E(\delta)=0, E(\varepsilon)=0$. Tidak ada korelasi antara $\varepsilon$ dengan $\boldsymbol{\eta}, \boldsymbol{\xi}, \boldsymbol{\delta}$, dan tidak ada korelasi antara $\boldsymbol{\delta}$ dengan $\boldsymbol{\xi}, \boldsymbol{\eta}, \boldsymbol{\varepsilon}$.

\subsection{Model Confirmatory Factor Analysis (CFA)}

Ada dua macam analisis faktor yaitu Exploratory Factor Analysis (EFA) dan Confirmatory Factor Analysis (CFA). EFA merupakan suatu metode untuk menemukan berapa jumlah faktor yang dapat digunakan untuk menjelaska hubungan antara sejumlah variabel yang dapat diamati dan variabel mana yang sangat berpengaruh terhadap faktor tersebut. Sedangkan CFA mengukur, melakukan pengujian dan mengkonfirmasi suatu, faktor yang telah terbentuk berdasarkan pada penelitian sebelumnya. Dalam penelitian ini, analisis faktor yang digunakan adalah CFA. Model persamaan untuk CFA yaitu sebagai berikut.

$$
\mathbf{x}=\boldsymbol{\Lambda} \xi+\varepsilon
$$

dimana $\Lambda$ adalah matrik faktor loading, $\xi$ adalah variabel laten, dan $\varepsilon$ adalah matrik error pengukuran. 
Dalam CFA, $\xi$ berdistribusi $\mathrm{N}[0, \Phi]$ dengan kovarians dari matrik $\Phi$ definit positif sehinggan matriks varian dan kovarian untuk $\boldsymbol{x}$ dirumuskan sebagai berikut.

$$
\Sigma=\Lambda \Phi \Lambda^{\mathrm{T}}+\Psi_{\varepsilon}
$$

\subsection{SEM dengan Pendekatan Bayesian}

Bayesian didasarkan pada teorema Bayes yang menyatakan bahwa peluang bersyarat A dengan suatu nilai $B$ yang diketahui akan sama dengan:

$$
p(A \mid B)=\frac{p(B \mid A) p(A)}{p(B)} \propto p(B \mid A) p(A)
$$

Untuk suatu data observasi $y$ dan parameter yang tidak diketahui $\theta$, distribusi bersamanya $(p(\theta, y))$ merupakan perkalian dua densitas, yaitu distribusi prior $(p(\theta))$ dan distribusi sampel, distribusi data, informasi data $(p(y \mid \theta))$ (Gelman, Carlin, Stern dan Rubin, 2004). Yang ditulis sebagai:

$$
p(\theta, y)=p(\theta) p(y \mid \theta)
$$

Berdasarkan teorema Bayes pada persamaan (6), maka akan diperoleh distribusi posterior sebagai berikut:

$$
p(\theta \mid y) \propto p(y \mid \theta) p(\theta)
$$

Distribusi posterior merupakan konsep dasar dari Bayesian, dimana distribusi posterior akan proporsional terhadap perkalian antara distribusi prior dan likelihood. Distribusi prior merupakan distribusi yang merujuk pada data masa lalu. Sedangkan likelihood merupakan fungsi dari untuk suatu data observasi yang telah diketahui.

Pendekatan Bayesian pada SEM menggunakan masukan data observasi tanpa matrik kovarians dari data (Lee, 2007). Estimasi Bayesiannya dapat dituliskan sebagai berikut:

$p(Y, \theta \mid M)=p(Y, \theta \mid M) p(\theta)=p(\theta \mid Y, M) p(Y \mid M)$ $p(Y \mid M)$ tidak tergantung $\theta$ dan dengan menganggap $\mathrm{Y}$ telah ditentukan dan konstan, maka:

$\log p(\theta \mid Y, M) \propto \log p(Y \mid \theta, M)+\log p(\theta)$

Metode SEM standar difokuskan pada matriks kovarian S. Penggunaan matriks kovarian ini sangat dipengaruhi oleh asumsi yang harus dipenuhi seperti variabel yang diobservasi memiliki distribusi normal multivariat dan jumlah observasi harus relatif besar.

Lee (2007) mengembangkan analisis SEM berdasarkan observasi individu melalui pendekatan Bayesian. Strategi yang digunakan dalam analisis SEM yang kompleks dilakukan 
dengan: (i) menerapkan ide dari data augmentation untuk menambah data pengamatan $Y$ dengan jumlah yang tidak diketahui, yang bisa merupakan variabel laten, data hilang atau yang lainnya yang menyebabkan kesulitan dalam estimasi parameter, kemudian bekerja dengan distribusi posterior gabungan (joint posterior distribution) dalam analisis posterior, (ii) menerapkan MCMC dan mengambil pengamatan dalam penghitungan statistik dari full condition distribution. Dalam literatur statistik pendekatan bayesian merupakan pendekatan yang powerfull dalam menganalisis model-model yang kompleks dan distribusi satanya yang bervariasi.

\subsection{Estimasi Bayesian}

Dalam SEM standar, dengan pendekatan maximum like lihood misalnya, $\theta$ tidak dianggap sebagai variabel random dimana $\theta$ adalah $\Phi, \psi, \Lambda, \Gamma$, B. Sedangkan dalam SEM pendekatan Bayesian, $\boldsymbol{\theta}$ dipertimbangkan sebagai random dengan distribusi (yang disebut distribusi prior). Bayesian didasarkan pada data observasi $Y$ dan distribusi prior untuk $\theta$.

Diketahui $p(\theta \mid \mathrm{Y}, \mathrm{M})$ adalah fungsi kepadatan probabilitas dari joint distribution dari $\mathbf{Y}$ dan $\boldsymbol{\theta}$ dibawah $\mathrm{M}$. Sifat dari $\boldsymbol{\theta}$ dibawah data $\mathrm{Y}$ dijelaskan secara lengkap oleh conditional distribution dari $\theta$ berdasarkan $\mathrm{Y}$. Conditional distribution inilah yang disebut distribusi posterior untuk $\theta$.

\subsection{Distribusi Prior}

Prior adalah informasi awal nilai parameter dalam model. Pada dasarnya ada dua jenis distribusi prior yaitu distribusi prior non-informative dan distribusi prior informative. Distribui prior non-informative berhubungan dengan situasi dimana distribusi prior tidak memiliki basis populasi. Distibusi prior non-informative digunakan ketika hanya terdapat sedikit informasi prior sehingga distibusi prior berperan minimal dalam distribusi posterior. Sumber informasi untuk distibusi prior informative, bisa didapat dari distibusi salah satu data terkait atau pengetahuan subjektif para ahli. Sebuah distribusi prior informative dapat memiliki parameter sendiri yang disebut hyperparameters.

Distribusi prior informative yang biasa digunakan dalam pendekatan Bayesian secara umum untuk permasalahan statistika adalah conjugate prior distribution. Pada conjugate prior distribution biasanya ditetapkan nilai fix yang diketahui untuk hyperparameters. Hyperparameters bisa didapatkan dari penelitian sebelumnya.

Untuk model analisis faktor yang berhubungan dengan persamaan pengukuran dirumuskan sebagai berikut. 
$\mathbf{y}_{i}=\Lambda \omega_{i}+\varepsilon_{i}$

dimana $\mathbf{y}_{i(\mathrm{p} \times 1)}$ merupakan vektor random pengamatan, $\Lambda_{(p \times q)}$ merupakan matriks loading factor. Sedangkan $\boldsymbol{\omega}_{\mathbf{i}}$ dipartisi ke dalam ( $\left.q_{1} \times 1\right)$ merupakan vektor variabel laten eksogen $\xi_{1}$ dan $\left(q_{2} \times 1\right)$ merupakan vektor variabel laten endogen $\eta_{1}$. Sehingga persamaan struktural yang menyatakan hubungan antara variabel laten endogen dan eksogen adalah sebagai berikut.

$$
\boldsymbol{\eta}_{\mathbf{i}}=\tilde{\mathbf{O}} \boldsymbol{\eta}_{\mathbf{i}}+\boldsymbol{\Gamma} \xi_{\mathbf{i}}+\boldsymbol{\delta}_{\mathbf{i}}
$$

dimana $\Pi_{(q 2 \times q)}$ dan $\left.\Gamma_{(q 2} \times q\right)$ merupakan matrik parameter dari koefisien regresi, dan $\delta_{i}$ adalah vektor error $\left(q_{1} \times 1\right)$ dengan asumsi bahwa $\xi_{i}$ berdistribusi $N[0, \Phi]$ dan $\delta_{i}$ berdistribusi $N\left[0, \boldsymbol{\psi}_{\overline{0}}\right]$ dan $\psi_{\delta}$ adalah matrik diagonal dengan elemen $\psi_{\mathrm{ck}}$ dan antara $\delta_{i}$ dan $\omega_{i}$ independen.

Apabila hyperparameters dalam conjugate prior distribution tidak diketahui, hyperparameters tersebut dapat dianggap sebagai parameter yang tidak diketahui dan dengan demikian memiliki distibusi sendiri dalam analisis Bayesian. Distibusi hyperprior ini memiliki hyperparameters sendiri. Sebagai hasilnya masalah akan menjadi tidak menarik. Oleh karena itu, untuk memudahkan, biasanya ditetapkan nilai yang diketahui untuk hyperparameters dalam conjugate prior distribution (Lee, 2007).

\subsection{Analisis Posterior}

Estimasi Bayesian dari $\theta$ biasanya didefiniskan melalui nilai mean atau modus dari $p(\theta \mid Y)$. Mc Donald (1975) dan Lee (1981) dalam Lee (2007) menjelaskan bahwa estimasi Bayesian dari $\theta$ dalam model EFA dan CFA berasal dari nilai modus dari log $p(\theta \mid \mathrm{Y})$ dengan bekerja secara langsung mencari nilai maksimum dari

$$
\log p(\theta \mid Y)+\log p(\theta)
$$

Secara teori, mean dari distibusi posterior $(\theta \mid Y)$ bisa didapatkan melalui integral. Sedangkan pada umumnya, integral tersebut tidak memiliki closed form. Namun, jika digunakan simulasi dengan sampel yang cukup besar dari $(\theta \mid Y)$ (atau dari $p(\theta \mid Y)$ ), maka dapat diperkirakan nilai mean dan atau nilai statistik lain yang berguna melalui simulasi pengamatan tersebut. Oleh karena itu, untuk mengatasi masalah tersebut, penting untuk mengembangkan metode yang efisien untuk menggambarkan observasi dari distribusi posterior. 


\section{Hasil dan Pembahasan}

\subsection{Rancangan model struktural (path diagram)}

Penelitian ini menggunakan dataset yang terdiri atas 21 variabel indikator secara keseluruhan dari 26 objek pengamatan. Variabel-variabel indikator tersebut menggambarkan empat variabel tidak terukur yakni: komitmen profesional (KP), komitmen organisasional (KO), perilaku kerja $(\mathrm{PK})$ dan kinerja kerja $(\mathrm{KK})$. Tiga variabel yang disebut lebih awal diduga memiliki pengaruh secara simultan terhadap kinerja kerja (KK), Oleh karena itu dirancang dua model struktural yang berbeda dengan tujuan untuk melihat hubungan yang berbeda antar keempat variabel.

\subsection{Penentuan prior parameter model}

Dalam analisis Bayesian, estimasi parameter dalam SEM harus ditentukan nilai hyperparameter yang diperlukan untuk membentuk distribusi prior. Nilai hyperparameter ini diketahui berdasarkan informasi dari studi sebelumnya. Distibusi prior memegang peranan penting karena digunakan dalam pembentukan distribusi posterior. Penggunaan hyperparameter untuk persamaan pengukuran akan berbeda dengan penggunaan hyperparameter untuk persamaan struktural.

Dalam penentuan prior pada penelitian ini digunakan mengacu pada Lee (2007) yaitu conjugate prior.

$\psi_{\mathrm{ck}} \stackrel{D}{\Rightarrow}$ Inverted Gamma $\left(\alpha^{*}{ }_{0 € \mathrm{k}}, \beta^{*} 0 \mathrm{\epsilon k}\right)$ atau ekuivalen dengan $\psi_{\mathrm{\epsilon k}}{ }^{-1} \stackrel{D}{\Rightarrow}$ Gamma $\left(\alpha_{0 € \mathrm{k}}, \beta_{0 \mathrm{ck}}\right)$ dan $\left[\Lambda_{k} \mid \psi_{\mathrm{ck}} \stackrel{D}{\Rightarrow} \mathrm{N}\left[\Lambda_{\mathrm{ok}}, \psi_{\mathrm{ck}} \mathrm{H}_{\mathrm{oyk}}\right]\right.$

Penentuan nilai parameter untuk distribusi conjugate prior untuk distribusi conjugate prior pada hasil penelitian sebelumnya (Lee, 2007). Distribusi prior yang digunakan dalam penelitian ini disajikan dalam Tabel 1.

Tabel 1 : Disribusi-distribusi prioryang digunakan untuk estimasi parameter

\begin{tabular}{|c|c|}
\hline Parameter Model 1 & Parameter Model 2 \\
\hline$\theta_{\delta} \sim$ Inverse $\operatorname{Gamma}(20,8)$ & $\theta_{\delta} \sim$ Inverse $\operatorname{Gamma}(20,8)$ \\
\hline$\theta_{\varepsilon} \sim$ Inverse $\operatorname{Gamma}(20,8)$ & $\theta_{\varepsilon} \sim$ Inverse $\operatorname{Gamma}(20,8)$ \\
\hline$\left[\Lambda_{x} \mid \theta_{\delta}\right] \sim \operatorname{Normal}\left(0.8 ; 4 \theta_{\delta}\right)$ & {$\left[\Lambda_{x} \mid \theta_{\delta}\right] \sim \operatorname{Normal}\left(0.8 ; 4 \theta_{\delta}\right)$} \\
\hline$\left[\Lambda_{y} \mid \theta_{\varepsilon}\right] \sim \operatorname{Normal}\left(0.8 ; 4 \theta_{\varepsilon}\right)$ & {$\left[\Lambda_{y} \mid \theta_{\varepsilon}\right] \sim \operatorname{Normal}\left(0.8 ; 4 \theta_{\varepsilon}\right)$} \\
\hline$\xi \sim \operatorname{Normal}(0, \phi)$ & $\xi \sim$ Multivariate Normal $(0, \phi)$ \\
\hline $\begin{array}{l}\phi \sim \chi_{(30)}^{2} \\
\beta_{2,1}, \beta_{3,1}, \beta_{3,2} \sim \operatorname{Normal}(0.6,10 \theta)\end{array}$ & $\phi \sim I W\left(\left[\begin{array}{cc}10 & 0 \\
0 & 10\end{array}\right], 30\right)$ \\
\hline
\end{tabular}


$\gamma_{1,1}, \gamma_{2,1} \sim \operatorname{Normal}(1.3,4 \theta)$

$\gamma_{1,1}, \gamma_{1,2}, \gamma_{1,3}, \gamma_{1,4}, \gamma_{1,5} \sim \operatorname{Normal}(1.3,4 \theta)$

$\theta \sim$ Inverse Gamma $(20,8)$

$\theta \sim$ Inverse Gamma(20,8)

\subsection{Penentuan threshold untuk data}

Data awal yang digunakan pada penelitian ini merupakan data kategorik. Dalam analisis menggunakan data kategori seperti ini, memperlakukan data dengan membentuk frekuensi dan proporsi dari data terdebut dan memberikan threshold yang berasal dari distribusi kontinu normal merupakan pendekatan yang lebih baik (Lee, 2007). Luasan wilayah tiap kategori diproporsikan berdasarkan frekuensi tiap kategori terpilih. Sehingga dalam penghitungan threshold diperlukan informasi frekuensi tiap kategori per variabel indikator. Setelah didapatkan frekuensi dari masing-masing variabel indikator, langkah selanjutnya adalah membentuk masing-masing kategori dalam proporsi terhadap total untuk selanjutnya dari proporsi tersebut dibawa ke dalam distribusi kontinu normal untuk mendapatkan nilai threshold nya.

\subsection{Estimasi parameter model struktural 1}

Rancangan hubungan antara komitmen professional terhadap komitmen organisasional, perilaku kerja dan kinerja kerja digambarkan pada diagram jalur (path diagram) Gambar 1a. Berdasarkan diagram jalur tersebut dapat diidentifikasi satu variabel laten yang berperan sebagai eksogen (KP) dan tiga variabel laten endogen (KO, PK dan KK) beserta 21 variabel indikator baik untuk variabel laten eksogen maupun endogen.

Hasil pendugaan dan pengujian parameter bagi model struktural dan pengukuran diringkas dalam Tabel 3.3. Berdasarkan Tabel 3.3 dan path diagram (Gambar 3.1) dapat digambarkan bahwa pada taraf signifikansi $5 \%$, variabel eksogen KP berpengaruh signifikan terhadap kedua variabel endogen $\mathrm{KO}$ dan $\mathrm{PK}$ dengan koefisien regresi secara berurutan bernilai 0.871 dan 0.939 . Pada taraf signifikansi yang sama, komitmen organisasional (KO) tidak berpengaruh signifikan terhadap perilaku kerja (PK), sedangkan kedua variabel tersebut berpengaruh signifikan terhadap kinerja kerja $(K O)$ dengan koefisien regresi secara berurutan bernilai 0.539 dan 0.642 . Semua indikator yang digunakan dalam penelitian ini berpengaruh signifikan terhadap keempat variabel laten.

Persamaan struktural dan pengukuran dapat dituliskan secara matematis sebagai berikut: 
1. Persamaan pengukuran variabel laten eksogen

$\left[\begin{array}{l}\mathrm{KP}_{1} \\ \mathrm{KP}_{2} \\ \mathrm{KP}_{3} \\ \mathrm{KP}_{4} \\ \mathrm{KP}_{5} \\ \mathrm{KP}_{6}\end{array}\right]=\left[\begin{array}{c}1 \\ 0.9431 \\ 0.9379 \\ 0.9905 \\ 1.0050 \\ 0.9729\end{array}\right]\left[\xi_{1}\right]+\left[\begin{array}{l}\delta_{1} \\ \delta_{2} \\ \delta_{3} \\ \delta_{4} \\ \delta_{5} \\ \delta_{6}\end{array}\right]$

2. Persamaan pengukuran variabel laten endogen

$\left[\begin{array}{l}\mathrm{KO}_{1} \\ \mathrm{KO}_{2} \\ \mathrm{KO}_{3} \\ \mathrm{KO}_{4} \\ \mathrm{KO}_{5} \\ \mathrm{PK}_{1} \\ \mathrm{PK}_{2} \\ \mathrm{PK}_{3} \\ \mathrm{PK}_{4} \\ \mathrm{PK}_{5} \\ \mathrm{KK}_{1} \\ \mathrm{KK}_{2} \\ \mathrm{KK}_{3} \\ \mathrm{KK}_{4} \\ \mathrm{KK}_{5}\end{array}\right]=\left[\begin{array}{ccc}1 & 0 & 0 \\ 0.9077 & 0 & 0 \\ 0.9463 & 0 & 0 \\ 0.9088 & 0 & 0 \\ 0.9923 & 0 & 0 \\ 0 & 1 & 0 \\ 0 & 0.7713 & 0 \\ 0 & 0.7849 & 0 \\ 0 & 0.7665 & 0 \\ 0 & 0.6964 & 0 \\ 0 & 0 & 1 \\ 0 & 0 & 0.8681 \\ 0 & 0 & 0.7438 \\ 0 & 0 & 0.7514 \\ 0 & 0 & 0.7864\end{array}\right]\left[\begin{array}{l}\eta_{1} \\ \eta_{2} \\ \eta_{3}\end{array}\right]+\left[\begin{array}{c}\varepsilon_{1} \\ \varepsilon_{2} \\ \varepsilon_{3} \\ \varepsilon_{4} \\ \varepsilon_{5} \\ \varepsilon_{6} \\ \varepsilon_{7} \\ \varepsilon_{8} \\ \varepsilon_{9} \\ \varepsilon_{10} \\ \varepsilon_{11} \\ \varepsilon_{12} \\ \varepsilon_{13} \\ \varepsilon_{14} \\ \varepsilon_{15}\end{array}\right]$

3. Persamaan struktural

$$
\left[\begin{array}{l}
\eta_{1} \\
\eta_{2} \\
\eta_{3}
\end{array}\right]=\left[\begin{array}{ccc}
0 & 0 & 0 \\
0.2523 & 0 & 0 \\
0.5399 & 0.6420 & 0
\end{array}\right]\left[\begin{array}{l}
\eta_{1} \\
\eta_{2} \\
\eta_{3}
\end{array}\right]+\left[\begin{array}{c}
0.8710 \\
0.9396 \\
0
\end{array}\right] \xi_{1}+\left[\begin{array}{c}
\zeta_{1} \\
\zeta_{2} \\
\zeta_{3}
\end{array}\right]
$$




\subsection{Estimasi parameter model struktural 2}

Pengolahan data pada penelitian ini menggunakan bantuan paket program WinBUGS 1.4 dengan struktur algoritma yang terdapat pada Lampiran 1. Dengan iterasi sebanyak 10.000 kali, proses estimasi parameter model telah mencapai burn in.

Hasil estimasi parameter pada Tabel 3.4 menunjukkan bahwa semua variabel memiliki pengaruh positif dengan koefisien yang bervariasi. Besar kecilnya nilai $\lambda$ dan $y$ dapat diartikan sebagai besar kecilnya pengaruh suatu variabel yang dipengaruhi. Dengan menggunakan selang kepercayaan sebesar $95 \%$, semua variabel mempunyai nilai yang signifikan, kecuali

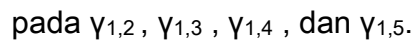

Berdasarkan nilai estimasi parameter pada Tabel 3.4, model 2 dapat dijelaskan bahwa besarnya pengaruh variabel KO dan KPA terhadap KK secara berturut-turut adalah sebesar 0.5679 dan 0.5128 , dan berpengaruh secara signifikan pada taraf signifikansi $5 \%$. Sedangkan ketiga variabel yang lain, yaitu KPB, PKA, dan PKB mempunyai pengaruh yang tidak signifikan terhadap KK. Dari hasil estimasi parameter tersebut, maka bentuk persamaan pengukuran untuk variabel eksogen dan variabel endogen dan persamaan struktural yang didapatkan adalah sebagai berikut :

1. Matriks Persamaan Pengukuran variabel eksogen

$\left[\begin{array}{l}K O_{1} \\ K O_{2} \\ K O_{3} \\ K P_{1} \\ K P_{2} \\ K P_{3} \\ K P_{4} \\ K P_{5} \\ K P_{6} \\ P K_{1} \\ P K_{2} \\ P K_{3} \\ P K_{4} \\ P K_{5}\end{array}\right]=\left[\begin{array}{lllll}1 & 0 & 0 & 0 & 0 \\ 0 & 1 & 0 & 0 & 0 \\ 0 & 0.8372 & 0 & 0 & 0 \\ 0 & 0 & 1 & 0 & 0 \\ 0 & 0 & 0.8245 & 0 & 0 \\ 0 & 0 & 0.8827 & 0 & 0 \\ 0 & 0 & 0 & 1 & 0 \\ 0 & 0 & 0 & 0.9177 & 0 \\ 0 & 0 & 0 & 0.7831 & 0 \\ 0^{2} & 0 & 0 & 0 & 0 \\ \delta_{3} \\ \delta_{4} \\ \xi_{3} \\ \xi_{4} \\ \xi_{5}\end{array}\right]+\left[\begin{array}{l}\delta_{1} \\ \delta_{2} \\ \delta_{1} \\ \delta_{6} \\ \delta_{8} \\ \delta_{9} \\ \delta_{10} \\ \delta_{11} \\ \delta_{12} \\ \delta_{13} \\ \delta_{14}\end{array}\right]$


2. Matriks Persamaan Pengukuran variabel endogen

$$
\left[\begin{array}{l}
K K_{1} \\
K K_{2} \\
K K_{3} \\
K K_{4} \\
K K_{5}
\end{array}\right]=\left[\begin{array}{c}
1 \\
0.7758 \\
0.7878 \\
0.7692 \\
0.7004
\end{array}\right]\left[\eta_{1}\right]+\left[\begin{array}{c}
\varepsilon_{1} \\
\varepsilon_{2} \\
\varepsilon_{3} \\
\varepsilon_{4} \\
\varepsilon_{5}
\end{array}\right]
$$

3. Persamaan Struktural

$$
\eta_{1}=0.5679 \xi_{1}+0.5128 \xi_{2}+0.4542 \xi_{3}+0.03762 \xi_{4}+0.318 \xi_{5}+\zeta_{1}
$$

\subsection{Analisis residual}

Penentuan nilai hyperparameter yang nantinya akan digunakan dalam distribusi prior ditujukan untuk menghasilkan residual terkecil yang nilainya mendekati nol. Berikut ini hasil nilai residual yang mendekati nol dengan nilai hyperparamter yang telah ditentukan dalam penggunaannya di distribusi prior. Dari hasil diketahui bahwa menggunakan distribusi prior dengan hyperparameter untuk model struktural 1, nilai error yang dihasilkan mendekati nol, yaitu nilai rata-rata kesalahan pengukuran variabel indikator pada variabel laten eksogen $\left(\theta_{\delta}\right)$ sebesar 0.298 dan rata-rata kesalahan pengukuran variabel indikator pada laten endogen sebesar $\left(\theta_{\varepsilon}\right)$ sebesar 0.305 . Sedangkan untuk nilai rata-rata kesalahan pengukuran variabel laten endogen $(\zeta)$ adalah sebesar -0.0376 yangmendekati nol. Hal ini membuktikan bahwa pemilihan penggunaan prior tersebut sudah tepat untuk melakukan estimasi parameter dalam model struktural 1. Sedangkan hasil untuk model struktural 2, nilai error yang dihasilkan mendekati nol, yaitu nilai rata-rata kesalahan pengukuran variabel indikator pada variabel laten eksogen $\left(\theta_{\delta}\right)$ sebesar 0.312 dan rata-rata kesalahan pengukuran variabel indikator pada laten endogen sebesar $\left(\theta_{\varepsilon}\right)$ sebesar 0.298 . Sedangkan nilai kesalahan pengukuran variabel laten endogen $(\zeta$ ) adalah sebesar -0.159 yang mendekati nol. Hal ini membuktikan bahwa pemilihan penggunaan prior tersebut sudah tepat untuk melakukan estimasi parameter dalam model struktural 2.

\subsection{Analisis Kelinieran Variabel Laten}

Dalam tahapan ini, akan diketahui apakah hubungan antara masing-masing variabel laten eksogen memiliki hubungan yang linier terhadap masing-masing variabel laten endogen. Hal ini dapat diidentifikasi secara visual melalui scatter plot antara variabel laten baik eksogen maupun endogen. 

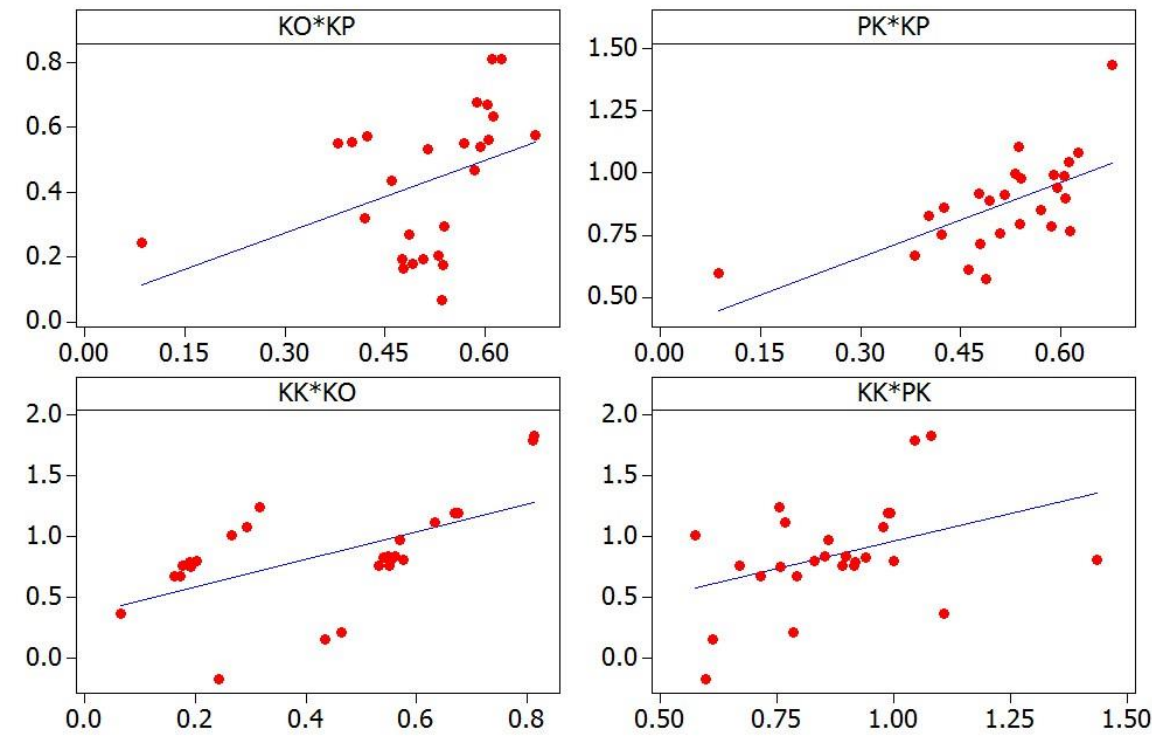

Gambar $1 \quad$ : Scatter Plot antara $\eta_{1}$ dengan setiap $\xi_{i}$ pada Model 1

Scatterplot of KK (eta) vs KO (xi1), KPA (xi2), KPB (xi3), ...

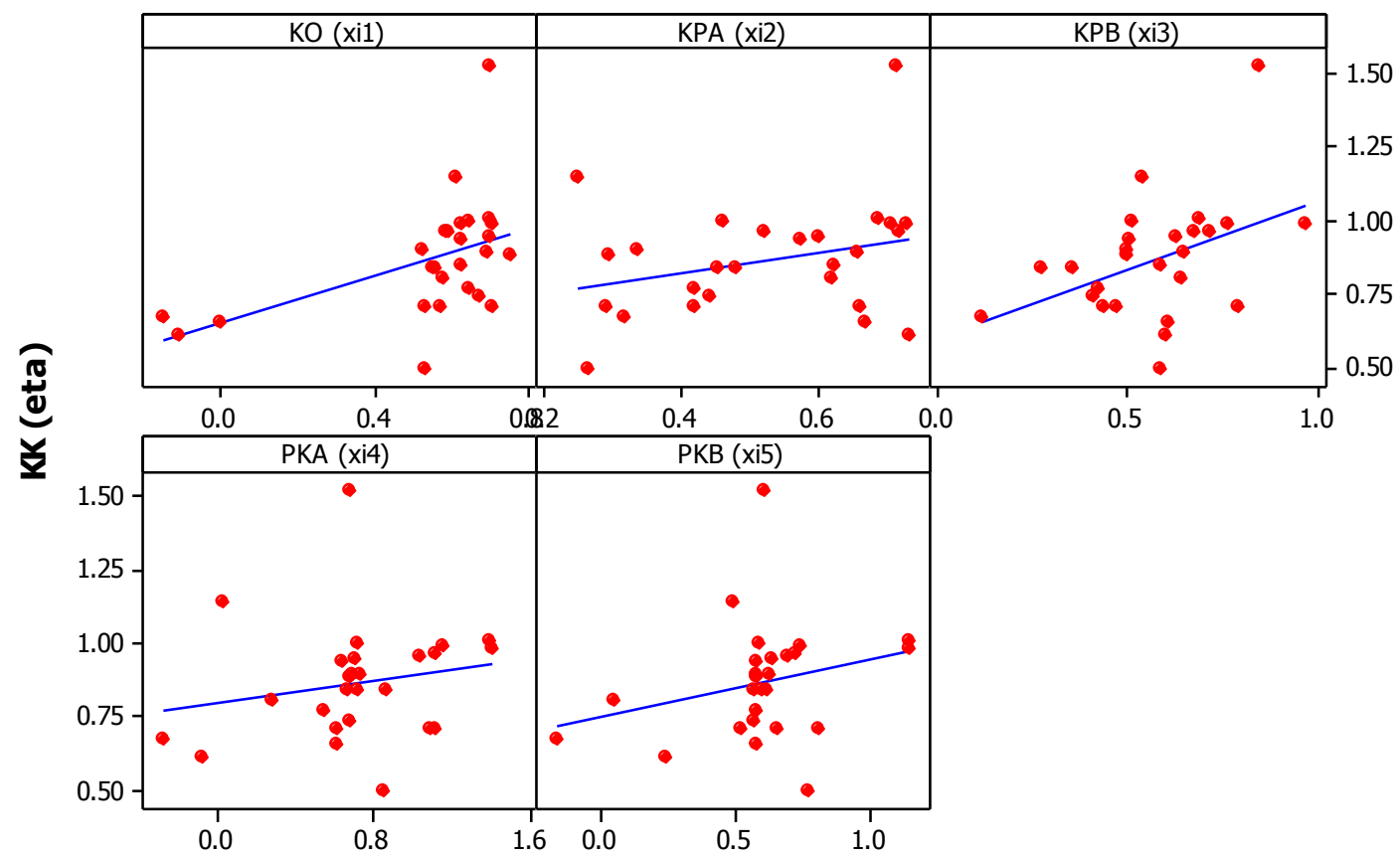

Gambar $2 \quad:$ Scatter Plot antara $\eta_{1}$ dengan setiap $\xi_{i}$ pada Model 2 
Berdasarkan Gambar 3.3 dan Gambar 3.4 terlihat bahwa pola hubungan yang terbentuk antara masing-masing variabel laten eksogen $\xi_{i}$ dengan variabel laten endogen $\eta_{1}$ pada model 1 dan model 2 adalah linier.

\section{KESIMPULAN}

Berdasarkan analisis model struktural 1 dan 2 diperoleh kesimpulan bahwa kedua model memberikan hasil yang informatif mengenai bagaimana komitmen profesiona (KP), komitmen organisasional $(\mathrm{KO})$, dan perilaku kerja (PK) berpengaruh terhadap kinerja kerja (KK). Model pertama menunjukkan bahwa KP berpengaruh terhadap KO dan PK, di sisi lain PK dan KO juga memberi kontribusi terhadap KK. Sedangkan model kedua menunjukkan bahwa KO dan $\mathrm{KP}(\mathrm{A})$ saja yang berpengaruh signifikan terhadap KK.

\section{DAFTAR PUSTAKA}

Bollen, K. A. .1989. Structural Equation with Latent Variables. Dept. Of Sociology The University of North Carolina. Chapel Hill North Carolina.

Lee, S.Y. 2007. Structural Equation Modeling: A Bayesian Approach. John Wiley \& Sons. Ltd.

Solimun. 2002. Structural Equation Modeling (SEM) Lisrel dan Amos. Malang: Fakultas MIPA Universitas Brawijaya. 